\title{
Is There an Association between Sleep Disorders and Diabetic Foot? A Scoping Review
}

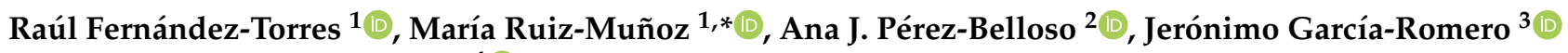 \\ and Manuel Gónzalez-Sánchez ${ }^{4}$ (i) \\ 1 Department of Nursing and Podiatry, University of Málaga, Arquitecto Francisco Peñalosa, s/n, \\ Ampliación Campus de Teatinos, 29071 Málaga, Spain; raulft.95@gmail.com \\ 2 Department of Podiatry, Faculty of Nursing, Physiotherapy and Podiatry, University of Sevilla, \\ 41009 Sevilla, Spain; aperez30@us.es \\ 3 Medical School of Physical Education and Sports, University of Málaga, C/Jiménez Fraud 10, Edificio López \\ de Peñalver, 29010 Málaga, Spain; jeronimo@uma.es \\ 4 Department of Physiotherapy, University of Málaga, Arquitecto Francisco Peñalosa, s/n, \\ Ampliación Campus de Teatinos, 29071 Málaga, Spain; mgsa23@uma.es \\ * Correspondence: marumu@uma.es; Tel.: +34-951-95-2315
}

Citation: Fernández-Torres, $\mathrm{R}$.

Ruiz-Muñoz, M.; Pérez-Belloso, A.J.; García-Romero, J.

Gónzalez-Sánchez, M. Is There an Association between Sleep Disorders and Diabetic Foot? A Scoping Review. J. Clin. Med. 2021, 10, 2530.

https://doi.org/10.3390/jcm10112530

Academic Editor: Katrien Benhalima

Received: 17 March 2021

Accepted: 3 June 2021

Published: 7 June 2021

Publisher's Note: MDPI stays neutral with regard to jurisdictional claims in published maps and institutional affiliations.

Copyright: (c) 2021 by the authors. Licensee MDPI, Basel, Switzerland. This article is an open access article distributed under the terms and conditions of the Creative Commons Attribution (CC BY) license (https:// creativecommons.org/licenses/by/ $4.0 /)$.

\begin{abstract}
Diabetic foot is associated with a low quality of life since physical disabilities, mood disturbances and psychological disorders are frequent. One of the most important biological processes to ensure quality of life is sleep. Sleep disorders can impair glycemic control in patients with diabetes mellitus or even cause long-term type 2 diabetes mellitus. The aim of this study is to carry out a scoping review about the association between sleep cycle disorders and diabetic foot. PubMed, Scopus, CINAHL, PEDro, Cochrane Library, SCIELO and EMBASE databases were chosen for the search and the following terms were used: "diabetic foot", "sleep*", "rest-activity", "mood" and "behavior". All the studies should include outcome variables about sleep and diabetic foot. Finally, 12 articles were selected, all of whichwere observational. The most frequent variables were those regarding diabetic foot ulcer aspects and diabetic neuropathy on one side, and obstructive sleep apnea, sleep duration and sleep quality on the other side. The results suggest that there is a possible association between obstructive sleep apnea and the presence or history of diabetic foot ulcers. No direct associations between sleep quality or sleep duration and diabetic foot or diabetic foot ulcer variables have been found.
\end{abstract}

Keywords: diabetic foot; diabetic foot ulcer; diabetic neuropathy; sleep; obstructive sleep apnea

\section{Introduction}

In many cases, diabetes mellitus (DM) leads to several complications, of which diabetic foot (DF) is one of the most frequent [1]. It likely begins with the onset of diabetic neuropathy (DN) and peripheral arterial disease (PAD) [2].Unless this situation is prevented, it can result in diabetic foot ulcers (DFUs), which tend to become infected and show poor healing [3,4]. The risk of developing wounds is $25 \%$ higher in a patient with DM [5]. The most advanced stage of DFU often requires lower limb amputation, and this is an important source of diabetes mortality [6]. Along with the mortality and morbidity of DFUs, the economic consequences are high. In Europe, the cost of treating DFUs varies from approximately 4500 to 16,800 EUR per patient [7].

DF is associated with a low quality of life, since physical disabilities and mood disturbances (among other situations) are frequent [8]. Psychological disorders, such as anxiety and depression, are also not uncommon [9]. Pain is another important factor affecting quality of life, caused by the existence of DFUs, DN and PAD symptoms [10,11], phantom limb syndrome [12] or the combination of all of these. 
One of the most important biological processes to ensure quality of life is sleep, which can be altered due to sleep disorders, lifestyle, psychosocial and environmental factors, or medical conditions [13].

In fact, sleep disturbances are identified as a disruptive event that favors the appearance and chronification of pathologies. Furthermore, it has been identified that this disturbance is bidirectional, in the sense that the treatments carried out in patients with chronic pathologies have a lesser effect when they suffer from sleep disturbances [14]. Among the main effects that cause sleep disturbance are depression, fatigue, exhaustion, decreased quality of life and cardiac, systemic and metabolic alterations [14,15]. Specifically, in patients with DM, it has been observed that sleep disturbances cause alterations in glycemic control [16], a fundamental variable in the management of these patients, causing, in the long term, an increase in patients with type 2 DM [17].

Despite the fact that it has been shown that sleep disorders are directly and negatively related to the appearance, capacity for adaptation and response and possibilities of recovery from chronic diseases, to the best of our knowledge, there are no reviews published that study the association between sleep disorders and DF, either directly (due to pathophysiological reasons) or indirectly (due to psychogenic issues derived from the pathology).

The main objective of the present study is to carry out a scoping review of the literature about the association between sleep disorders and DF.

\section{Materials and Methods}

This review was carried out according to the guidelines and recommendations of the Preferred Reported Items for Systematic Reviews and Meta-Analysis (PRISMA) [18].

\subsection{Search and Sources}

PubMed (Medline), Scopus, CINAHL, PEDro, Cochrane Library, SCIELO and EMBASE databases were used. The following terms were used alongside "OR" or "AND": "diabetic foot", "sleep*", "rest-activity","mood", "behavior".

The following database search strategy was used: ((((Sleep* [Title/Abstract]) OR Rest-Activity [Title/Abstract]) OR Mood [Title/Abstract]) OR Behavior [Title/Abstract]) AND (diabetic foot [Title/Abstract]).

\subsection{Eligibility Criteria}

The inclusion criteria were that studies should be observational, experimental or mixed. In these studies, the sample should consist of patients with DF. Age, sex and the type of diabetes of the sample were not considered. All documents published up to 30 July 2020 were included. The exclusion criteria were the absence of outcome variables about sleep or DF, and studies that were not conducted on humans. Documents not published in English, Spanish, German, French or Italian were also excluded.

\subsection{Selection of Studies}

Two independent researchers were involved in each stage of the study selection. Initially, a screening was carried out based on the title and abstract of the articles resulting from the search strategy, checking the contents of the full article if necessary. The articles were then evaluated for selection based on the previously mentioned eligibility criteria. Disagreement between the articles chosen by each reviewer was solved by the intervention of a third reviewer, who ultimately decided if a study was included or excluded.

\subsection{Data Extraction and Synthesis of Results}

In order to have a general approach to the studies, a Table 1 was designed to show their structural characteristics: authors, date of publication, type of study, sample size, type of diabetes, gender and age. In Table 2, the outcome variables regarding DF and sleep were presented. This table included information such as the characteristics of DFUs, DN, sleep quality, insomnia and breathing disorders, among others. These outcome variables 
were extracted to analyze how often were they were studied and to determine which were the most relevant, thus facilitating the comparison of results between studies.

After the extraction and comparison of the variables related to DF and sleep, Table 3 was constructed to show the associations found in the selected studies.

\section{Results}

\subsection{Selection of Studies}

The flowdiagram (Figure 1) summarizes the study selection process, specifying the reasons for study exclusion. The main reason for exclusion was the absence of variables related to the sleep cycle or DF in the main objective of the study. There were 12 articles selected that were published since 2009 and included DF and sleep outcome variables.

All selected studies were observational, most of them cross-sectional $(n=6)$. The remaining studies were cohort studies $(n=2)$, case-control studies $(n=2)$, one case-report and one case series study. The sample size varied from $n=3$ [19] to $n=1,656,739$ [20], with the total sample size being $n=1,659,699$. In 3studies [21-23], the type of diabetes in the sample was not specified. In 6studies [19,20,24-27], the sample subjects had type 2 diabetes mellitus (DM2), and in 3studies [28-30], they had both type 1diabetes mellitus (DM1)and DM2. In all of them, the population was adults(>18 years old) (Table 1$)$.

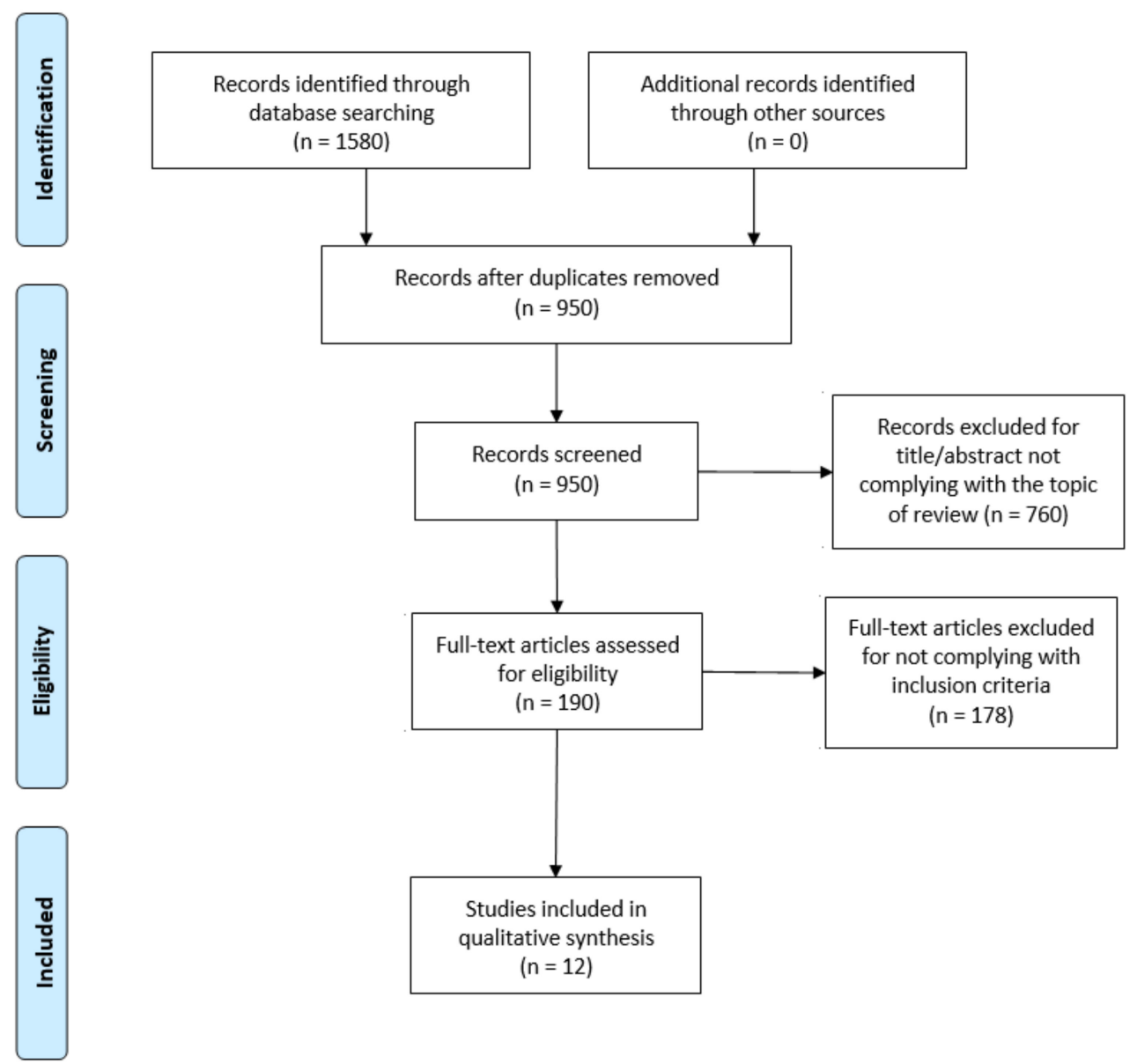

Figure 1. PRISMA flow diagram adapted with permission from The PRISMA group, 2020. 
Table 1. Structural characteristics of the included studies.

\begin{tabular}{|c|c|c|c|c|c|}
\hline Authors (Year) & Type of Study & Sample Size & Diabetes Type & Gender & Age (Mean \pm SD) \\
\hline Altaf et al. (2016) [24] & $\begin{array}{c}\text { Observational } \\
\text { CSS }\end{array}$ & $\mathrm{n}=234$ & 2 & $\begin{array}{l}M=48 \\
F=186\end{array}$ & Range: $59,6-62,6$ \\
\hline Andruskiene et al. (2013) [21] & $\begin{array}{c}\text { Observational } \\
\text { CSS }\end{array}$ & $\mathrm{n}=1602$ & - & $\begin{array}{l}M=600 \\
F=1002\end{array}$ & Range: $25-64$ \\
\hline Bener et al. (2016) [25] & $\begin{array}{c}\text { Observational } \\
\text { CSS }\end{array}$ & $\mathrm{n}=459$ & 2 & $\begin{array}{c}M=201 \\
F=258\end{array}$ & $\begin{array}{l}48,2 \pm 9,0 \\
47,1 \pm 8,3\end{array}$ \\
\hline Nair (2018) [22] & $\begin{array}{c}\text { Observational } \\
\text { CSe }\end{array}$ & $\mathrm{n}=100$ & - & $\begin{array}{c}\mathrm{M}=66 \\
\mathrm{~F}=34\end{array}$ & Range: 18-90 \\
\hline Haveleia and Gayatri (2019) [23] & $\begin{array}{c}\text { Observational } \\
\text { CSS }\end{array}$ & $\mathrm{n}=97$ & - & $\begin{array}{c}\mathrm{M}=43 \\
\mathrm{~F}=54\end{array}$ & $54,84 \pm 1,71$ \\
\hline Maltese et al. (2018) [28] & $\begin{array}{c}\text { Observational } \\
\text { CoS } \\
\text { Prospective }\end{array}$ & $\mathrm{n}=94$ & $\begin{array}{l}1(n=28) \\
2(n=66)\end{array}$ & $\begin{array}{l}M=69 \% \\
F=31 \%\end{array}$ & $\begin{array}{l}51,5 \pm 16,2 \\
62,7 \pm 12,0\end{array}$ \\
\hline Puspita et al. (2019) [26] & $\begin{array}{c}\text { Observational } \\
\text { CSS }\end{array}$ & $\mathrm{n}=152$ & 2 & $\begin{array}{l}\mathrm{M}=35.5 \% \\
\mathrm{~F}=64.5 \%\end{array}$ & $57 \pm 8,61$ \\
\hline Rutkove et al. (2009) [29] & $\begin{array}{c}\text { Observational } \\
\text { CoS } \\
\text { Prospective }\end{array}$ & $\mathrm{n}=82$ & $\begin{array}{l}1 \\
2\end{array}$ & $\begin{array}{l}M=- \\
F=-\end{array}$ & Range: $18-80$ \\
\hline Salomé et al. (2013) [30] & $\begin{array}{c}\text { Observational } \\
\text { CSS }\end{array}$ & $\mathrm{n}=60$ & $\begin{array}{l}1(n=27) \\
2(n=33)\end{array}$ & $\begin{array}{l}M=55 \% \\
F=45 \%\end{array}$ & Range: $34-71$ \\
\hline Sheahan et al. (2017) [27] & $\begin{array}{c}\text { Observational } \\
\text { C-CS }\end{array}$ & $\mathrm{n}=77$ & 2 & $\begin{array}{l}M=50 \\
F=27\end{array}$ & $61 \pm 11$ \\
\hline Subramanian et al. (2019) [20] & $\begin{array}{l}\text { Observational } \\
\text { C-CS } \\
\text { Retrospective }\end{array}$ & $\mathrm{n}=1,656,739$ & 2 & $\begin{array}{c}M=902,868 \\
F=753,871\end{array}$ & $64.7 \pm 13,3$ \\
\hline Vas et al. (2016) [19] & $\begin{array}{c}\text { Observational } \\
\text { CR }\end{array}$ & Three cases & 2 & $\begin{array}{c}M=3 \\
F=0\end{array}$ & Range: 57,61 - 63 \\
\hline
\end{tabular}

Abbreviations: year (Year of publication); SD (Standard Deviation); CoS (Cohort study); C-CS (Case-control study); CSS (Cross-sectional study); CR (Case report); CSe (Case series); M (Male); F (Female).

\subsection{Data Extraction and Synthesis of Results}

The outcome variables analyzed in the studies were divided into DF-related and sleep-related. The most frequent variables in the first group were those regarding DFU aspects, followed by those related to DN. In the second group, the most frequent variables were those regarding obstructive sleep apnea (OSA), sleep duration and sleep quality (Table 2). All studies defined the instruments for measuring the outcome variables, except for the studies by Bener et al. [25] and Andruskiene et al. [21].

Table 3 shows a summary of the findings of the selected studies. All of them were observational, so there was no intervention to be considered and no quantitative analysis could be performed on the results. OSA showed an association with the development of DN and PAD, the severity of DFUs, the history of DFUs and healing capacity. Sleep quality was associated with the use of certain therapies for DFU healing and showed contrary associations with the presence of DFUs. Sleep duration was not associated with the presence of DFUs but was associated with the level of amputation. 
Table 2. Outcome variables related to the sleep and diabetic foot.

\begin{tabular}{|c|c|c|c|c|}
\hline Authors (Year) & DF Variables & DF Measurement Tools & SC Variables & SC Measurement Tools \\
\hline $\begin{array}{c}\text { Altaf et al. (2016) } \\
{[24]}\end{array}$ & $\begin{array}{c}\text { - Diabetic } \\
\text { neuropathy } \\
\text { - Presence of } \\
\text { DFU } \\
\text { - Small fiber } \\
\text { neuropathy }\end{array}$ & $\begin{array}{l}\text { - Michigan Neuropathy } \\
\text { Screening Instrument } \\
\text { - PARP activation } \\
\text { - Intraepidermalnervefiber } \\
\text { density }\end{array}$ & - Presence of OSA & $\begin{array}{c}\text { - Overnight } \\
\text { cardio-respiratory device } \\
\text { - Apnea/Hypopnea Index }\end{array}$ \\
\hline $\begin{array}{l}\text { Andruskiene et al. } \\
\qquad \text { (2013) [21] }\end{array}$ & $\begin{array}{l}\text { - Diabetic foot } \\
\text { pain }\end{array}$ & Unknown & $\begin{array}{l}\text { - Problems of falling asleep } \\
\text { - Night-time awakenings } \\
\text { - Self-rated sleep quality } \\
\text { - Sleep latency period } \\
\text { - Sleepiness in daytime } \\
\text { - Taking naps } \\
\text { - Using of sleeping pills }\end{array}$ & $\begin{array}{c}\text { - Basic Nordic Sleep } \\
\text { Questionnaire (BNSQ) }\end{array}$ \\
\hline $\begin{array}{l}\text { Bener et al. (2016) } \\
\text { [25] }\end{array}$ & $\begin{array}{c}\text { - Diabetic } \\
\text { neuropathy } \\
\text { - Presence of } \\
\text { DFU }\end{array}$ & - Observation & $\begin{array}{l}\text { - Sleep duration } \\
\text { - Sleep loss } \\
\text { - Sleep disturbances }\end{array}$ & - Hours \\
\hline $\begin{array}{l}\text { Nair } \\
(2018) \\
{[22]}\end{array}$ & $\begin{array}{l}\text { - } \\
\text { Inflammatory } \\
\text { symptoms } \\
\text { - Vasodilation } \\
\text { - Gait }\end{array}$ & $\begin{array}{c}\text { - Leg swelling, foot stiffness } \\
\text { - Skin discoloration, sensation, } \\
\text { leg heaviness, }\end{array}$ & - Sleep quality & Unknown \\
\hline $\begin{array}{l}\text { Haveleia and } \\
\text { Gayatri (2019) } \\
\text { [23] }\end{array}$ & $\begin{array}{l}\text { - Presence of } \\
\text { DFU } \\
\text { - Duration of } \\
\text { DFU }\end{array}$ & Observation & - Sleep quality & - PSQI \\
\hline $\begin{array}{l}\text { Maltese et al. } \\
\text { (2018) [28] }\end{array}$ & $\begin{array}{l}\text { - DFU severity } \\
\text { - DFU } \\
\text { persistence } \\
\text { - DFU } \\
\text { recurrence }\end{array}$ & $\begin{array}{l}\text { - SINBAD scale } \\
\text { - Non-healing in 12-month } \\
\text { period } \\
\text { - Re-ulceration in a healed site }\end{array}$ & - Risk of OSA & $\begin{array}{l}\text { - STOP-BANG } \\
\text { Questionnaire }\end{array}$ \\
\hline $\begin{array}{l}\text { Puspita et al. } \\
\text { (2019) [26] }\end{array}$ & $\begin{array}{l}\text { - Duration of } \\
\text { DFU } \\
\text { - DFU } \\
\text { assessment }\end{array}$ & $\begin{array}{l}-</>6 \text { months } \\
\text { - Wagner scale }\end{array}$ & - Sleep quality & - PSQI \\
\hline $\begin{array}{l}\text { Rutkove et al. } \\
\text { (2009) [29] }\end{array}$ & $\begin{array}{l}\text { - Foot } \\
\text { temperature } \\
\text { - Nerve } \\
\text { conduction } \\
\text { studies } \\
\text { - Quantitative } \\
\text { sensory } \\
\text { testing } \\
\text { - Diabetic } \\
\text { Neuropathy }\end{array}$ & $\begin{array}{l}\text { - iButton } \\
\text { - TSA-II NeuroSensory } \\
\text { Analyzer } \\
\text { - MNSI } \\
\text { - UENS }\end{array}$ & $\begin{array}{l}\text { Same as besides, but } \\
\text { measurements were done } \\
\text { while asleep vs. awake }\end{array}$ & $\begin{array}{c}\text { - iButton } \\
\text { - TSA-IINeuroSensory } \\
\text { Analyzer } \\
\text { - MNSI } \\
\text { - UENS }\end{array}$ \\
\hline $\begin{array}{l}\text { Salomé et al. } \\
\text { (2013) [30] }\end{array}$ & $\begin{array}{l}\text { - Presence of } \\
\text { DFU }\end{array}$ & - Observation & - Sleep quality & - PSQI \\
\hline $\begin{array}{l}\text { Sheahan et al. } \\
\text { (2017) [27] }\end{array}$ & $\begin{array}{c}\text { - Foot } \\
\text { deformity } \\
\text { - DFU surface } \\
\text { area } \\
\text { - DFU } \\
\text { infection } \\
\text { - DFU depth } \\
\text { - Amputation } \\
\text { level }\end{array}$ & $\begin{array}{c}\text { - Small muscle wastage, bony } \\
\text { prominence, prominent } \\
\text { metatarsal heads, } \\
\text { hammer/claw toes, limited } \\
\text { joint mobility or Charcot } \\
\text { deformity } \\
\text { - Longest edge and widest edge } \\
\text { - University of Texas scale } \\
\text { - IWGDF classification }\end{array}$ & $\begin{array}{l}\text { - Daytime sleeping } \\
\text { - Lying down duration } \\
\text { - Sleep duration }\end{array}$ & $\begin{array}{c}\text { - Epworth Sleepiness Scale } \\
\text { - Minutes } \\
\text { - Minutes }\end{array}$ \\
\hline
\end{tabular}


Table 2. Cont.

\begin{tabular}{|c|c|c|c|c|}
\hline Authors (Year) & DF Variables & DF Measurement Tools & SC Variables & SC Measurement Tools \\
\hline $\begin{array}{l}\text { Subramanian et al. } \\
\text { (2019) [20] }\end{array}$ & $\begin{array}{l}\text { - Diabetes- } \\
\text { related foot } \\
\text { disease }\end{array}$ & $\begin{array}{l}\text { - Signs of amputation, } \\
\text { gangrene, presence of DFU, } \\
\text { Charcot foot, peripheral } \\
\text { vascular disease and } \\
\text { peripheral neuropathy }\end{array}$ & - Presence of OSA & $\begin{array}{c}\text { - Previous medical } \\
\text { diagnosis }\end{array}$ \\
\hline $\begin{array}{c}\text { Vas et al. (2016) } \\
\text { [19] }\end{array}$ & $\begin{array}{c}\text { - Presence of } \\
\text { DFU } \\
- \\
\text { Osteomyelitis } \\
\text { - DFU healing }\end{array}$ & $\begin{array}{c}\text { - Observation } \\
\text { - MRI } \\
\text { - Observation }\end{array}$ & - Presence of OSA & $\begin{array}{c}\text { - Previous medical } \\
\text { diagnosis }\end{array}$ \\
\hline
\end{tabular}

Abbreviations: DF: diabetic foot; SC: sleep; PARP: poly ADP ribosepolymerase; OSA: obstructive sleep apnea; DFU: diabetic foot ulcer; PSQI: Pittsburgh sleep quality index; MNSI: Michigan neuropathy screening index; UENS: Utah early neuropathy scale; MRI: magnetic resonance imaging.

Table 3. Findings of selected studies that relate variables of the diabetic foot and variables of the sleep.

\begin{tabular}{|c|c|c|}
\hline $\begin{array}{c}\text { Sleep } \\
\text { Variable }\end{array}$ & Diabetic Foot Variable & Findings \\
\hline \multirow{6}{*}{ OSA } & IENFD & $\begin{array}{c}\text { - Negative correlation }(p<0.001) \text { between IENFD and OSA that implies small } \\
\text { fiber neuropathy [24] }\end{array}$ \\
\hline & MNSI & - Mild OSA was associated with past history of DFU( $p=0.016)[24]$ \\
\hline & History of DFU & - Positive correlation with OSA presence $(p=0.022)[24]$ \\
\hline & PARP & $\begin{array}{l}\text { - Positive correlation }(p=0.025) \text { between PARP and OSA that involves } \\
\text { endothelial dysfunction [24] }\end{array}$ \\
\hline & DF presence & - DF was significantly predictive of OSA [20] \\
\hline & DFU healing & $\begin{array}{l}\text { - CPAP therapy for OSA led to DFU healing in patients under treatment [19] } \\
\text { - High risk of OSA led to poor DFU healing [28] }\end{array}$ \\
\hline \multirow[t]{2}{*}{ Sleep quality } & DFU healing & - Microcurrent therapy for DFU led to a significantly better sleep quality [22] \\
\hline & DFU presence & $\begin{array}{c}\text { - Subjective sleep quality showed significant disparity with comprehensive sleep } \\
\text { quality (PQSI) [23] } \\
\text { - Poor sleep quality was significantly related to pain level }(p=0.013)[26] \\
\text { - No significant difference in sleep quality of people with diabetes with and } \\
\text { without DFU [26] } \\
\text { - Pain ( } p: 0.048 \text { ) and stress ( } p \text { : } 0.001 \text { ) were significantly related to poor sleep } \\
\text { quality [23] } \\
\text { - Patients with DFU had poor sleep quality (Salomé et al., 2013) }\end{array}$ \\
\hline \multirow[t]{2}{*}{$\begin{array}{l}\text { Sleep } \\
\text { duration }\end{array}$} & Minor amputation presence & $\begin{array}{l}\text { - Patients with minor amputation had lower Epworth Sleepiness Scale score } \\
\text { (lower score = normal) than those without amputation [27] }\end{array}$ \\
\hline & DFU presence & $\begin{array}{c}\text { - DFU group showed no differences from DM and/or DN groups in lying down } \\
\text { duration and sleep duration [27] }\end{array}$ \\
\hline
\end{tabular}

Abbreviations: OSA: obstructive sleep apnea; DFU: diabetic foot ulcer; DF: diabetic foot; CPAP: continuous positive airway therapy; DM: diabetes mellitus; IENFD: intraepidermal nerve fiber density; MNSI: Michigan neuropathy screening instrument;PARP: poly ADP ribose polymerase; PSQI: Pittsburgh sleep quality index.

\section{Discussion}

Obstructive sleep apnea (OSA) is a common sleep disorder in which a partial or complete obstruction of the upper airway occurs [31]. These obstructions will lead to a greater division of sleep, a decrease in oxygen saturation and a reduction in air flow [32]. OSA is an independent risk factor for cardiovascular disease [33], cognitive disorders [34] 
and metabolic dysfunction [35].Intermittent hypoxia increases sympathetic activation and oxidative stress, impairing arterial function and generating inflammation [36].

It is known that untreated OSA leads to morbidity and worsening of glycemic control (insulin resistance and glucose intolerance), along with diabetic angiopathy. Research has shown that OSA is related to insensitivity of the foot and diabetic peripheral neuropathy, all of which contributes negatively to DFU healing [37,38]. In four of the studies included, DF variables were associated with OSA-related variables. Altaf et al. [24] found a positive correlation between small fiber neuropathy and OSA severity, and between the prevalence of DFUs and OSA. This suggested that OSA patients should be considered to be high risk, although the sample size did not allow regression analyses. Subramanian et al. [20] recommended anticipating the development of OSA as a risk factor in patients with DF.

Maltese et al. [28] highlighted the high prevalence of OSA among patients with DFUs, concluding that OSA severity is directly related to poor healing and re-ulceration.They used the STOP-Bang Questionnaire for OSA severity, a widely used instrument with high levels of sensitivity and specificity [39]. Therefore, the presence and severity of OSA should be considered in the treatment and prevention of DFUs. As a matter of fact, Vas et al. [19] described three cases of patients with DM2 and obesity, in which they studied how the impact of severe OSA interfered with DFU healing, despite a good local treatment. Patients under OSA treatment with continuous positive airway pressure showed significantly improved DFU healing, while patients who refused OSA treatment did not improve. Despite sample limitations, the results were promising and could represent a breakthrough in DFU treatment in patients with similar characteristics.

In another four of the studies included, sleep quality was related to DFU-related variables. Haveleia and Gayatri [23] found a significant correlation between the levels of stress and pain and subjective sleep quality in DFU patients, although they found no relationship between the severity of DFUs and sleep quality. However, it must be taken into account that this study did not include a control group in the sample. Conversely, Salomé et al. [30] did provide results that supported DFU patients having poor sleep quality, although this study did not include a control group without DFUs. Puspita et al. [26] addressed this same relationship and included a control group of people with diabetes without DFUs. As in the previous study, most of the subjects with DFUs and/or pain had poor sleep quality, although no significant differences were found.

All of these studies used the Pittsburgh sleep quality index (PSQI) to measure sleep quality, which is valid, reliable and widely used [40]. This lack of relationship between sleep quality and the presence or severity of DFUs could be explained by the high probability of DFUs not causing any pain (because of DN) [41]. Moreover, not all DFU patients suffer from sleep disorders [42].

Nairetet al. [22] analyzed the effectiveness of microcurrent therapy for the healing of chronic ulcers (including DFUs), and one of the outcome variables was sleep quality. Both sleep quality and neuropathic pain improved in most patients after receiving the therapy, however, the sleep quality measurement instrument was not specified, nor was a control group used. These results should be taken with caution and the use of microcurrent therapy should be studied in detail in future works.

Another important variable regarding sleep is its duration, which was studied by Sheahan et al. [27] in patients with DFUs under different conditions, as follows: minor amputation, major amputation, with and without off-loading elements, or peripheral neuropathy. These groups were compared to each other and did not show a significant decrease in quality or duration of sleep. This lack of correlation can be explained in a similar way as before, in that the absence of pain and psychogenic or sleep disorders may be the reason for the sleep not being impaired.

The study by Andruskiene et al. [21] found an association between diabetic foot pain and depressive states in a female population, however, no correlation was found with variables regarding the sleep. According to other authors, the depressive state can cause 
sleep disturbances $[43,44]$. This study was the only one included in this review that took into account the consumption of sedative, antidepressant, analgesic or antitussive drugs.

In two of the studies included, DF and sleep variables were not related to each other. In the study by Bener et al. [25], sleep variables and DF variables were studied separately as risk factors for hearing loss. Rutkove et al. [29] also did not relate them. Instead, thermoregulation in the foot and DN during sleep and wakefulness were measured, and it was concluded that nocturnal thermoregulation is affected in patients with ND.

Along with our results, recent systematic reviews and meta-analyses show the association between DM on the sleep. Reutrakul et al. [45] found an association between DM1, poor sleep quality and prevalence of OSA, while another review [46] also associated the latter with DM2. Lee et al. [47] and Grandner et al. [48] found that the quality and duration of sleep influenced both glycemic metabolism in patients with DM2 and the risk of suffering from DM2. Several authors concluded that there is a high prevalence of sleep disturbances in patients with DM $[35,49,50]$. In the recent work by Nefs et al. [51], the reciprocal relationship between DM and sleep was approached from a behavioral science perspective, and it was stated that sleep quality should be considered with the same importance as diet and exercise in DM care.

Our results lead to several applications in clinical practice. Since the relationship between OSA and DF is the most studied, clinicians should consider OSA as a component of the multifactorial condition of DF. In addition, it may be appropriate for a diabetic foot specialist and a sleep disorder specialist to work in a multidisciplinary way with OSA and DF patients, to address prevention and treatment strategies.

Although there is a lack of evidence on the relationship between DF and the quality and duration of sleep, it is known that DFU healing is associated with poor coping and high levels of depression [52], which in turn are associated with poor quality and duration of sleep [36]. To improve the multidisciplinary treatment of patients with DF and psychological disorders or sleep disturbances, research linking these variables should be conducted in the future.

One limitation of this study is that there might be scientific literature published in a different language than those included in the inclusion criteria. In addition, a trend to link sleep disturbances with neuropathic pain has been found in the available literature. However, since neuropathic pain is not exclusive to DF, studies concerning neuropathic pain have not been the topic of this review. The same can be said for PAD, which is multifactorial and not exclusive to DM, and thereforeit has not been considered in the present work either.

\section{Conclusions}

In conclusion, the results suggest that there is a possible association between OSA and the presence or history of DFUs. With respect to sleep quality and duration, no direct associations with DF or DFU variables have been found. It is strongly recommended that future studies, particularly randomized controlled trials, take into account interventions for OSA, sleep quality and sleep duration. These studies should employ highly valid and reliable measurement instruments, which are widely available.

Author Contributions: Conceptualization, M.R.-M. and M.G.-S.; Methodology, R.F.-T.; Validation, R.F.-T., A.J.P.-B. and J.G.-R.; Formal Analysis, M.G.-S.; Investigation, M.R.-M. and M.G.-S.; Resources, R.F.-T. and A.J.P.-B.; Data analysis, R.F.-T., A.J.P.-B. and J.G.-R.; Writing-Original Draft Preparation, R.F.-T.; Writing-Review and Editing, M.R.-M. and M.G.-S.; Visualization, M.R.-M.; Supervision, M.R.-M. and M.G.-S.; Project Administration, J.G.-R. All authors have read and agreed to the published version of the manuscript.

Funding: This research received no external funding.

Institutional Review Board Statement: Not applicable.

Informed Consent Statement: Not applicable. 
Conflicts of Interest: The authors declare no conflict of interest.

\section{References}

1. Harding, J.L.; Pavkov, M.E.; Magliano, D.J.; Shaw, J.E.; Gregg, E.W. Global trends in diabetes complications: A review of current evidence. Diabetologia 2019, 62, 3-16. [CrossRef]

2. Apelqvist, J. Diagnostics and treatment of the diabetic foot. Endocrine 2012, 41, 384-397. [CrossRef]

3. Jia, L.; Parker, C.; Parker, T.J.; Kinnear, E.M.; Derhy, P.H.; Alvarado, A.M.; Huygens, F.; Lazzarini, P.A. Incidence and risk factors for developing infection in patients presenting with uninfected diabetic foot ulcers. PLoS ONE 2017, 12, e0177916. [CrossRef] [PubMed]

4. Lowry, D.; Saeed, M.; Narendran, P.; Tiwari, A. The Difference between the Healing and the Nonhealing Diabetic Foot Ulcer: A Review of the Role of the Microcirculation. J. Diabetes Sci. Technol. 2016, 11, 914-923. [CrossRef]

5. Amin, N.; Doupis, J. Diabetic foot disease: From the evaluation of the "foot at risk" to the novel diabetic ulcer treatment mo-dalities. World J. Diabetes 2016, 7, 153-164. [CrossRef] [PubMed]

6. Jupiter, D.C.; Thorud, J.C.; Buckley, C.J.; Shibuya, N. The impact of foot ulceration and amputation on mortality in diabetic patients. I: From ulceration to death, a systematic review. Int. Wound J. 2016, 13, 892-903. [CrossRef] [PubMed]

7. Prompers, L.; Huijberts, M.; Schaper, N.; Apelqvist, J.; Bakker, K.; Edmonds, M.; Holstein, P.; Jude, E.; Jirkovska, A.; Mauricio, D.; et al. Resource utilisation and costs associated with the treatment of diabetic foot ulcers. Prospective data from the Eurodiale Study. Diabetologia 2008, 51, 1826-1834. [CrossRef]

8. Vileikyte, L. Diabetic foot ulcers: A quality of life issue. Diabetes Metab. Res. Rev. 2001, 17, 246-249. [CrossRef]

9. Udovichenko, O.V.; Maximova, N.V.; Amosova, M.V.; Yunilaynen, O.A.; Berseneva, E.A.; Starostina, E.G. Prevalence and Prognostic Value of Depression and Anxiety in Patients with Diabetic Foot Ulcers and Possibilities of their Treatment. Curr. Diabetes Rev. 2017, 13, 97-106. [CrossRef]

10. Sibbald, R.G.; Armstrong, D.G.; Orsted, H.L. Pain in diabetic foot ulcers. Ostomy Wound Manag. 2003, 49, 24-29.

11. Kaur, S.; Pandhi, P.; Dutta, P. Painful diabetic neuropathy: An update. Ann. Neurosci. 2011, 18, 168-175. [CrossRef]

12. Clark, R.L.; Bowling, F.L.; Jepson, F.; Rajbhandari, S. Phantom limb pain after amputation in diabetic patients does not differ from that after amputation in nondiabetic patients. Pain 2013, 154, 729-732. [CrossRef] [PubMed]

13. Medic, G.; Wille, M.; Hemels, M.E. Short- and long-term health consequences of sleep disruption. Nat. Sci. Sleep 2017, 9, 151-161. [CrossRef] [PubMed]

14. Leggett, A.; Assari, S.; Burgard, S.; Zivin, K. The effect of sleep disturbance on the association between chronic medical conditions and depressive symptoms over time. Longitud. Life Course Stud. 2017, 8, 138-151. [CrossRef]

15. Irwin, M.R. Why Sleep Is Important for Health: A Psychoneuroimmunology Perspective. Annu. Rev. Psychol. 2015, 66, 143-172. [CrossRef] [PubMed]

16. Zhu, B.-Q.; Li, X.-M.; Wang, D.; Yu, X.-F. Sleep quality and its impact on glycaemic control in patients with type 2 diabetes mellitus. Int. J. Nurs. Sci. 2014, 1, 260-265. [CrossRef]

17. Kawakami, N.; Takatsuka, N.; Shimizu, H. Sleep disturbance and onset of type 2 diabetes. Diabetes Care 2004, $27,282-283$. [CrossRef]

18. Moher, D.; Liberati, A.; Tetzlaff, J.; Altman, D.G.; The PRISMA Group. Preferred Reporting Items for Systematic Reviews and Meta-Analyses: The PRISMA Statement. PLoS Med. 2009, 6, e1000097. [CrossRef]

19. Vas, P.R.J.; Ahluwalia, R.; Manas, A.B.; Manu, C.; Kavarthapu, V.; Edmonds, M.E. Undiagnosed severe sleep apnoea and diabetic foot ulceration-A case series based hypothesis: A hitherto under emphasized factor in failure to heal. Diabet. Med. 2016, 33, e1-e4. [CrossRef] [PubMed]

20. Subramanian, A.; Adderley, N.J.; Tracy, A.; Taverner, T.; Hanif, W.; Toulis, K.A.; Thomas, G.N.; Tahrani, A.A.; Nirantharakumar, K. Risk of Incident Obstructive Sleep Apnea Among Patients with Type 2 Diabetes. Diabetes Care 2019, 42, 954-963. [CrossRef]

21. Andruškienè, J.; Podlipskytè, A.; Martinkènas, A.; Varoneckas, G. Depressive mood in association with sociodemographic, be-havioral, self-perceived health, and coronary artery disease risk factors and sleep complaints. Medicina 2013, 49, 372-378. [CrossRef]

22. Nair, H.K. Microcurrent as an adjunct therapy to accelerate chronic wound healing and reduce patient pain. J. Wound Care 2018, 27, 296-306. [CrossRef] [PubMed]

23. Haveleia, A.; Gayatri, D. Sleep quality and the affecting factors in patients with diabetic ulcer. Enferm. Clín. 2019, 29, 70-75. [CrossRef]

24. Altaf, Q.-A.A.; Ali, A.; Piya, M.K.; Raymond, N.T.; Tahrani, A.A. The relationship between obstructive sleep apnea and intraepidermal nerve fiber density, PARP activation and foot ulceration in patients with type 2 diabetes. J. Diabetes Its Complicat. 2016, 30, 1315-1320. [CrossRef]

25. Bener, A.; Al-Hamaq, A.O.; Abdulhadi, K.; Salahaldin, A.H.; Gansan, L. Interaction between diabetes mellitus and hypertension on risk of hearing loss in highly endogamous population. Diabetes Metab. Syndr. Clin. Res. Rev. 2017, 11, S45-S51. [CrossRef] [PubMed]

26. Puspita, A.D.; Gayatri, D.; Pujasari, H. Sleep quality in diabetic mellitus with diabetic foot ulcer. In AIP Conference Proceedings; AIP Publishing: Melville, NY, USA, 2019; Volume 2092, p. 040009. 
27. Sheahan, H.; Canning, K.; Refausse, N.; Kinnear, E.M.; Jorgensen, G.; Walsh, J.R.; Lazzarini, P. Differences in the daily activity of patients with diabetic foot ulcers compared to controls in their free-living environments. Int. Wound J. 2017, 14, 1175-1182. [CrossRef] [PubMed]

28. Maltese, G.; Fountoulakis, N.; Drakatos, P.; Shah, D.; Patel, K.; Sharma, A.; Thomas, S.; Pengo, M.; Karalliedde, J. Elevated obstructive sleep apnoea risk score is associated with poor healing of diabetic foot ulcers: A prospective cohort study. Diabet. Med. 2018, 35, 1494-1498. [CrossRef]

29. Rutkove, S.B.; Veves, A.; Mitsa, T.; Nie, R.; Fogerson, P.M.; Garmirian, L.P.; Nardin, R.A. Impaired Distal Thermoregulation in Diabetes and Diabetic Polyneuropathy. Diabetes Care 2009, 32, 671-676. [CrossRef] [PubMed]

30. Salomé, G.M.; de Souza Pellegrino, D.M.; Blanes, L.; Ferreira, L.M. Sleep Quality in Patients with Diabetic Foot Ulcers. Wounds 2013, 25, 20-27.

31. Mannarino, M.R.; Di, F.F.; Pirro, M. Obstructive sleep apnea syndrome. Eur. J. Intern. Med. 2012, 23, 586. [CrossRef] [PubMed]

32. Drager, L.F.; Togeiro, S.M.; Polotsky, V.Y.; Lorenzi-Filho, G. Obstructive sleep apnea: A cardiometabolic risk in obesity and the metabolic syndrome. J. Am. Coll. Cardiol. 2013, 62, 569-576. [CrossRef]

33. Oyama, J.-I.; Yamamoto, H.; Maeda, T.; Ito, A.; Node, K.; Makino, N. Continuous Positive Airway Pressure Therapy Improves Vascular Dysfunction and Decreases Oxidative Stress in Patients with the Metabolic Syndrome and Obstructive Sleep Apnea Syndrome. Clin. Cardiol. 2012, 35, 231-236. [CrossRef] [PubMed]

34. Ferini-Strambi, L.; Baietto, C.; Di Gioia, M.; Castaldi, P.; Castronovo, C.; Zucconi, M.; Cappa, S. Cognitive dysfunction in patients with obstructive sleep apnea (OSA): Partial reversibility after continuous positive airway pressure (CPAP). Brain Res. Bull. 2003, 61, 87-92. [CrossRef]

35. Reichmuth, K.J.; Austin, D.; Skatrud, J.B.; Young, T. Association of sleep apnea and type II diabetes: A population-based study. Am. J. Respir. Crit. Care Med. 2005, 172, 1590. [CrossRef]

36. Garvey, J.F.; Taylor, C.T.; McNicholas, W.T. Cardiovascular disease in obstructive sleep apnoea syndrome: The role of intermittent hypoxia and inflammation. Eur. Respir. J. 2009, 33, 1195-1205. [CrossRef] [PubMed]

37. Tahrani, A.A.; Ali, A.; Raymond, N.T.; Begum, S.; Dubb, K.; Mughal, S.; Jose, B.; Piya, M.K.; Barnett, A.H.; Stevens, M.J. Obstructive sleep apnea and diabetic neuropathy: A novel association in patients with type 2 diabetes. Diabetes Care 2012, 186, 434-441. [CrossRef] [PubMed]

38. Paiva, T.; Attarian, H. Obstructive sleep apnea and other sleep-related syndromes. Handb. Clin. Neurol. 2014, 119, 251-271. [CrossRef]

39. Nagappa, M.; Liao, P.; Wong, J.; Auckley, D.; Ramachandran, S.K.; Memtsoudis, S.G.; Mokhlesi, B.; Chung, F. Validation of the STOP-Bang Questionnaire as a Screening Tool for Obstructive Sleep Apnea among Different Populations: A Systematic Review and Meta-Analysis. PLoS ONE 2015, 10, e0143697. [CrossRef] [PubMed]

40. Backhaus, J.; Junghanns, K.; Broocks, A.; Riemann, D.; Hohagen, F. Test-retest reliability and validity of the Pittsburgh Sleep Quality Index in primary insomnia. J. Psychosom. Res. 2002, 53, 737-740. [CrossRef]

41. Yagihashi, S.; Mizukami, H.; Sugimoto, K. Mechanism of diabetic neuropathy: Where are we now and where to go? J. Diabetes Investig. 2010, 2, 18-32. [CrossRef]

42. Sridhar, G.; Madhu, K. Prevalence of sleep disturbances in diabetes mellitus. Diabetes Res. Clin. Pract. 1994, 23, 183-186. [CrossRef]

43. Murphy, M.J.; Peterson, M.J. Sleep Disturbances in Depression. Sleep Med. Clin. 2015, 10, 17-23. [CrossRef] [PubMed]

44. Nutt, D.; Wilson, S.; Paterson, L. Sleep disorders as core symptoms of depression. Dialogues Clin. Neurosci. 2008, 10, 329-336. [PubMed]

45. Reutrakul, S.; Mokhlesi, B. Obstructive Sleep Apnea and Diabetes: A State of the Art Review. Chest 2017, 152, 1070-1086. [CrossRef] [PubMed]

46. Fallahi, A.; Jamil, D.I.; Karimi, E.B.; Baghi, V.; Gheshlagh, R.G. Prevalence of obstructive sleep apnea in patients with type 2 diabetes: A systematic review and meta-analysis. Diabetes Metab. Syndr. Clin. Res. Rev. 2019, 13, 2463-2468. [CrossRef] [PubMed]

47. Lee, S.W.H.; Ng, K.Y.; Chin, W.K. The impact of sleep amount and sleep quality on glycemic control in type 2 diabetes: A systematic review and meta-analysis. Sleep Med. Rev. 2017, 31, 91-101. [CrossRef]

48. Grandner, M.A.; Seixas, A.; Shetty, S.; Shenoy, S. Sleep Duration and Diabetes Risk: Population Trends and Potential Mechanisms. Curr. Diabetes Rep. 2016, 16, 1-14. [CrossRef] [PubMed]

49. Chattu, V.K.; Chattu, S.K.; Burman, D.; Spence, D.W.; Pandi-Perumal, S.R. The Interlinked Rising Epidemic of Insufficient Sleep and Diabetes Mellitus. Health 2019, 7, 37. [CrossRef] [PubMed]

50. Narisawa, H.; Komada, Y.; Miwa, T.; Shikuma, J.; Sakurai, M.; Odawara, M.; Inoue, Y. Prevalence, symptomatic features, and factors associated with sleep disturbance/insomnia in Japanese patients with type-2 diabetes. Neuropsychiatr. Dis. Treat. 2017, 13, 1873-1880. [CrossRef] [PubMed]

51. Nefs, G.; Bazelmans, E.; Donga, E.; Tack, C.J.; De Galan, B. Sweet dreams or bitter nightmare: A narrative review of 25 years of research on the role of sleep in diabetes and the contributions of behavioural science. Diabet. Med. 2019, 37, 418-426. [CrossRef]

52. Vedhara, K.; Miles, J.N.V.; Wetherell, M.A.; Dawe, K.; Searle, A.; Tallon, D.; Cullum, N.; Day, A.; Dayan, C.; Drake, N.; et al. Coping style and depression influence the healing of diabetic foot ulcers: Observational and mechanistic evidence. Diabetology 2010, 53, 1590-1598. [CrossRef] [PubMed] 